\title{
Determinants of organizational citizenship behavior: A case study of higher education institutes in Pakistan
}

\author{
Nazia Bashir, Amber Sardar, Khalid Zaman*, Aamir Khan Swati and Shazia Fakhr
}

Department of Management Sciences, COMSATS Institute of Information Technology, Abbottabad, Pakistan

\begin{tabular}{|c|c|}
\hline ART I CLE I N FO & A B S T RA C T \\
\hline $\begin{array}{l}\text { Article history: } \\
\text { Received August 6, } 2011 \\
\text { Received in Revised form } \\
\text { August, 7, } 2011 \\
\text { Accepted } 8 \text { August } 2011 \\
\text { Available online } \\
\text { 12 August } 2011 \\
\text { Keywords: } \\
\text { Organizational citizenship } \\
\text { behavior (OCB) } \\
\text { Altruism } \\
\text { Conscientiousness } \\
\text { Civic virtue } \\
\text { Education sector } \\
\text { Khyber Pakhtonkhuwa } \\
\text { Pakistan }\end{array}$ & $\begin{array}{l}\text { This study empirically examines the relationship between altruism, conscientiousness, and civic } \\
\text { virtue, three of the antecedents of organizational citizenship behavior, in higher education } \\
\text { institutes in the Khyber Pakhtonkhuwa Province (KPK) of Pakistan. The study is based on } \\
\text { primary data collected from ninety-five employees of various institutes in Pakistan. The data is } \\
\text { analyzed using the techniques of rank correlation coefficient and multiple regression analysis. } \\
\text { All the findings are tested at } 0.01 \text { and } 0.05 \text { levels of significance. The result concludes that } \\
\text { altruism, conscientiousness, and civic virtue have strong positive impacts on the organizational } \\
\text { citizenship behavior in the context of higher education institutes in Pakistan. }\end{array}$ \\
\hline
\end{tabular}

\section{Introduction}

Organizational citizenship behavior (OCB) is relatively a new and emerging concept considered under organizational behavior. Major research, in this emerging field of study has taken place in the 1990s and continuing at an established speed. After the introduction of initial concepts of OCB (Bateman \& Organ, 1983), numerous studies followed by relating OCB with different dimensions of organizational performance. A great majority of existing studies about the relationship between OCB and performance are theoretical rather than empirical (Borman \& Motowidlo, 1993). Most of these suggest that OCB is positive for organizations and benefits both management and subordinates.

Managers value OCB because it creates a work environment conducive for cooperation. It saves the amount of time a manager spends on an issue and helps in focusing on several other opportunities for improving the organizational performances (Turnipseed \& Rassuli, 2005). However, empirical studies do not support a consistent relationship between OCB and performance. Jacqueline et al. (2004) conclude that OCB is like an extra-role behavior, which is not officially required by the organization; rather its practice depends solely on the consent of an employee as a consequence of the

* Corresponding author. Tel. +92-(0) 334-8982744

E-mail addresses: khalidzaman@ciit.net.pk (K. Zaman) 
organizational environment provided to that employee. OCB makes an important impact on organization's effectiveness; by adding to the social framework of the work environment (Todd, 2003). Despite the widespread interest in the topic of organizational citizenship behavior (OCB), little practical research has tested the basic assumption that these forms of behavior improve the effectiveness of work groups or organizations.

The objective of this study is to find out the relationship between antecedents and OCB in higher education institutes of Khyber Pakhtonkhuwa (KPK) province of Pakistan. More specific objectives are to find out:

- The effect of altruism on organizational citizenship behaviour,

- $\quad$ The effect of conscientiousness on organizational citizenship behaviour and

- The effect of civic virtue on organizational citizenship behaviour.

Based on the above objectives, the present study seeks to test the following hypothesis:

H1: $\quad$ There is a direct relationship between altruism and $O C B$.

H2: $\quad$ There is a direct relationship between conscientiousness and OCB.

H3: $\quad$ There is a direct relationship between civic virtue and $O C B$.

In this paper, an analysis has been carried out to find a relationship between OCB and their antecedents in the specific context of higher education institutes of Pakistan. This paper does not include all dimensions and factors of the OCB and anteceded but limited to the following variables:

- Organizational Citizenship Behavior (OCB): OCB is defined as an extra work associated with behaviors, which goes above and beyond the routine duties prescribed by their job descriptions or measured in formal evaluations (Bateman \& Organ, 1983).

- Altruism: Altruism is defined as the willingness of an employee to help a coworker. It is also referred as the selflessness of an employee towards organization. According to Redman \& Snape (2005), Altruism deals with going outside job requirements to help others with whom the individual has any interaction. Altruism is accounted as a one of the significant antecedents of OCB.

- Conscientiousness: It refers to discretionary behaviors, which goes outside the basic requirements of the job in terms of obeying work rules, attendance and job performance (Redman \& Snape, 2005). In other words, conscientiousness means the thorough adherence to organizational rules and procedures, even when no one is observing. It is considered as the mindfulness that a person never forgets to be a part of a system i.e. the organization. Conscientiousness, and openness are all better predictors of decision-making performance when adaptability is required than decision-making performance prior to unforeseen change.

- Civic Virtue: It refers to behaviors, which reveals a responsible concern for the image and wellbeing of the organization (Redman \& Snape, 2005). Baker (2005) explains civic virtue is responsible and productive involvement in the political processes of the organization.

The paper is organized as follows: after introduction, which is provided in this section, literature review is carried out in section 2. Data and methodological framework are explained in section 3. Results are shown in section 4 . Final section concludes the study.

\section{Literature review}

The relationship between OCB and their antecedents has been extensively explored in the past. However, relatively few researches have examined this relationship in the specific context of higher education institutes of Pakistan. The general interest in organizational citizenship stems primarily 
from the belief that these behaviors enhance organizational effectiveness. Because of this, a great deal of research (Ball et al. 1994; Bateman \& Organ, 1983; Brief \& Motowidlo, 1986; Farh, et al. 1990; George, 1990; George \& Bettenhausen, 1990; Moorman, 1991; Munene, 1995; Niehoff \& Moorman, 1993; Organ \& Konovsky, 1989; Organ \& Ryan, 1995; Podsakoff et al., 1996a, 1 996b; Podsakoff et al., 1993; Podsakoff et al., 1990; Podsakoff, Niehoff, MacKenzie, \&Williams, 1993; Puffer, 1987; Schnake, 1991; Smith et al., 1983; Williams \& Anderson, 1991) has attempted to spot those subordinate characteristics (e.g., conscientiousness, agreeableness, positive and negative affectivity, etc.), task characteristics (task scope, task feedback, intrinsically satisfying tasks, etc.), organizational characteristics (e.g., formalization, inflexibility, spatial distance, etc.), and/or leader behaviors (e.g., leader supportiveness, contingent reward behavior, transformational leadership behaviors, etc.) that encourage employees to exhibit OCBs. Considering all this activity, it is still surprising that more research has not attempted to practically test whether OCBs really do influence organizational effectiveness.

There are many factors that can contribute to the determination of OCB, which include Altruism, Conscientiousness, Civic virtue, Sportsmanship, Courtesy, etc. However, the factors that have been considered in this research to have a significant relationship with OCB, are the first three i.e. Altruism, Conscientiousness, and Civic Virtue. Accodring to Borman et al. (2001) Altruism and conscientiousness are the two major dimensions of OCB.

\subsubsection{Altruism}

Helping behaviors may directly contribute by enhancing morale and fostering group cohesiveness and a sense of belonging to a team, thus making the organization a more attractive place to work. Related to this, when employees exhibit sportsmanship by being willing to "roll with the punches," and refrain from complaining about trivial matters, it sets an example of putting the interests of the work unit or group ahead of one's own interests; thus enhancing a sense of loyalty and commitment to the organization.

Altruism and compassion (sympathy) may arise as a natural consequence of experiences of interconnection and oneness (Vieten et al., 2005). Altruism or helping coworkers makes the work system more efficient because one worker can utilize his or her slack time to assist another on a more urgent task by showing concerns towards his/her coworkers (Neihoff \& Yen, 2004). According to Rush and Allen (2001), an abundant body of social and psychological research indicates that there are gender differences with regard to helping behavior and altruism. Participants who were allowed to work individually were much more likely to engage in altruism and courtesy behaviors as found by Yorges (1999). The measure of altruism may be similar to citizenship behavior directed toward one's colleagues as established by Brennan \& Skarlicki (2004). Altruism encourages teamwork and cooperation by allowing employees to increase the pool of available knowledge and resources (Neihoff \& Yen, 2004).

\subsubsection{Conscientiousness}

According to Neihoff and Yen (2004), more conscientious employees will stay informed with up-todate knowledge about all products or services offered by the organization. Conscientiousness with its emphasis on responsibility and dedication is likely to underlie the first motive for interpersonal helping - taking the initiative to engage in behaviors for the good of the organization. Conscientiousness can be expressed in numerous ways in organizations and, most obviously, in terms of job performance (King et al., 2005). Conscientiousness affects important work outcomes (Roberts et al., 2005). Theoretically, conscientiousness may be an important predictor of workplace behaviors because it provides the organization a direction that is necessary to produce targeted behaviors (King et al., 2005). Higher values are associated with greater conscientiousness when combined (Yorges, 
1999). Conscientiousness accounted for unique variance in citizenship targeted toward the organization, as opined by Ladd and Henry (2000).

\subsubsection{Civic virtue}

Conscientiousness is significantly related to generalized compliance and to civic virtue (Konovsky \& Organ, 1996). There is an impact of fairness for only a single form of OCB that is civic virtue, as found by Bacharach \& Jex (2000). According to Redman \& Snape (2005), the civic virtue is positively predicted by commitment to customers and co-workers with evidence of fractional mediation by global commitment. Coole (2003) argues that civic virtue was more limited in their relation to organizational effectiveness; i.e. the more the organization is effective, the more chances of emergence of this aspect. Extraversion is negatively related to the citizenship behaviors of Altruism, Civic Virtue, and Conscientiousness (Baker, 2005). Civic virtue is more likely to involve a purposeful contribution by employees compared to other dimensions (Jacqueline et al., 2004). If employees identify strongly with the organization (i.e., high civic virtue), one would expect them to exert extra effort to improve their productivity, resulting in improved efficiency (Neihoff \& Yen, 2004).

\section{Theoretical framework}

This study has been conducted at individual level rather than corporate level as OCB and their antecedents concerned with individuals. OCB is taken as dependent variable while altruism, conscientiousness and civic virtue are taken as independent variables. The framework of the study is given in Fig. 1.

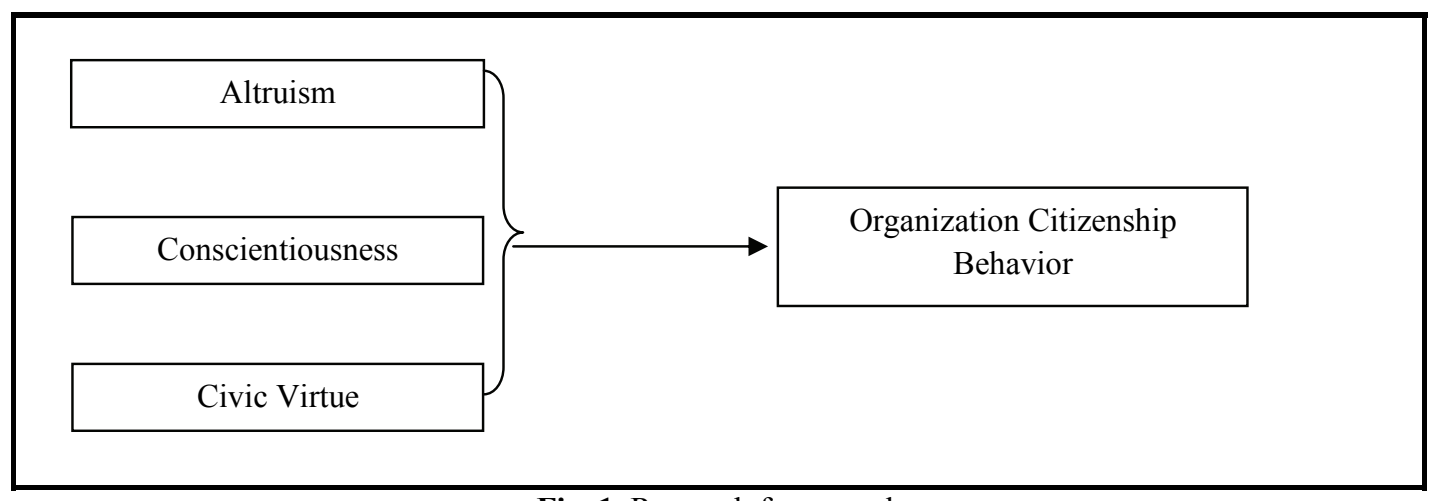

Fig. 1. Research framework

\subsection{Data collection}

Questionnaire was used for data collection. OCB measure developed by Lee and Allen (2002) and a measure of contextual performance developed by Motowidlo and Scotter (1994) are taken in this study. While, antecedents of OCB section of questionnaire i.e. Altruism, Conscientiousness, and Civic Virtue which are developed by Podsakoff et al., 1990 and Podsakoff \& MacKenzie, 1994 are taken. Five point Likert Scale ranging from 1 (Never) to 5 (Always) was used to measure responses. The respondents' scores for each construct were obtained by summing across all the item scores of the individual variables. The hypothesised relationships among the study variables depicted in the model were tested using multiple regressions. The respondents were assured of confidentiality to guarantee the fairness of responses. To avoid any oversight due to a non-serious attitude we tried to utilize the time off of employees to fill the questionnaires. Also the respondents were provided with full explanation of the questionnaire. 


\subsection{Sampling}

One hundred and twenty questionnaires were randomly distributed among the universities teachers of different higher education institutes in Khyber Pakhtonkhuwa Province of Pakistan, namely, COMSATS Institute of Information Technology, Abbottabad campus; Hazara University, Mansehra campus; UET, Abbottabad campus and COMWAVE, Abbottabad campus. Ninety four questionnaires were returned out of one hundred and twenty. Thus, the response rate was $78.3 \%$. The Cronbach's Alpha reliability coefficients for the sample are given in Table 1.

\section{Table 1}

Cronbach's Alpha Reliability Coefficients

\begin{tabular}{ll}
\hline Items & Cronbach's Alfa (r) \\
\hline Altruism & 0.83 \\
Conscientiousness & 0.90 \\
Civic Virtue & 0.74 \\
\hline
\end{tabular}

\section{Results and discussion}

\subsection{Demographic data analysis}

Table 2 shows the frequency distribution based on age, gender, qualification and job experience. The demographic data shows that thirty five respondents were between 20 to 30 years of age, thirty eight people were between 31 to 40 years which is the largest pool of respondents. Twelve respondents were between 41 to 50 years, six people between 51 to 60 years and three people were between 61 to 70 years of age. The qualification category shows that forty four people were having 16 years of education while the qualification of fifty respondents were 18 or more than 18 years, which shows that our respondents are well educated. There were fifty nine males and thirty five female respondents. Eleven people were having less than 2 years teaching experience, forty eight people were having experience between 2 to 5 years and thirty five people had 5 or more than 5 years of teaching experience.

Table 2

Demographic data

\begin{tabular}{llll}
\hline Description & & & \\
\hline \multirow{4}{*}{ Age } & $20-30$ years & 35 & 37 \\
& $31-40$ years & 38 & 40 \\
& $41-50$ years & 12 & 13 \\
\hline Qualification & $51-60$ years & 6 & 7 \\
& 61-70 years & 3 & 3 \\
\hline \multirow{2}{*}{ Gender } & 16 years & 44 & 56 \\
& 18 yeas or more & 50 & 63 \\
\hline \multirow{2}{*}{ Experience } & Male & 59 & 37 \\
& female & 35 & 11 \\
& Less than 2 years & 11 & 52 \\
\hline
\end{tabular}

\subsection{Correlation analysis}

In this section, the results of the inferential statistical techniques used in the study are presented. Descriptive statistics and correlation co-efficient is calculated in Table 3. 
Table 3

Descriptive Statistics and Correlation Matrix

\begin{tabular}{|c|c|c|c|c|}
\hline Predictors & $\begin{array}{r}\text { Mean Standard } \\
\text { deviation }\end{array}$ & OCB & Altruism & ConscientiousnessCivic virtue \\
\hline$\overline{\mathrm{OCB}}$ & 3.85960 .3749 & 1.000 & & \\
\hline Altruism & 3.64740 .5783 & $0.413 *$ & 1.000 & \\
\hline Conscientio & s4.29050.5877 & $0.381 *$ & 0.035 & 1.000 \\
\hline Civic Virtue & 3.77190 .5354 & $0.387^{*}$ & $0.334 *$ & 0.075 \\
\hline
\end{tabular}

*Correlation is significant at the 0.01 level (2-tailed)

The result reveals that the mean value of organization citizenship behavior, altruism, conscientiousness and civic virtue are 3.859, 3.647, 4.290 and 3.771, respectively. While their standard deviations are between the ranges of 0.376 to 0.587 , which shows how close the response values towards their means. In addition, the results of correlation matrix support our study hypothesis i.e., there is a direct and positive relationship between antecedents and OCB.

\subsection{Regression analysis}

The value for the R-square in Table 4 is 0.553 , which endorses that $55.3 \%$ of the variation in the dependent variable is explained by the independent variables of the model. The $44.7 \%$ variation in the dependent variable remains unexplained by the independent variables of the study. F-value is higher than its critical value suggesting a better overall significance of the estimated model. Thus, fitness of the model is acceptable empirically.

Table 4

Regression Model: Dependent Variable: Organization citizenship behavior (OCB)

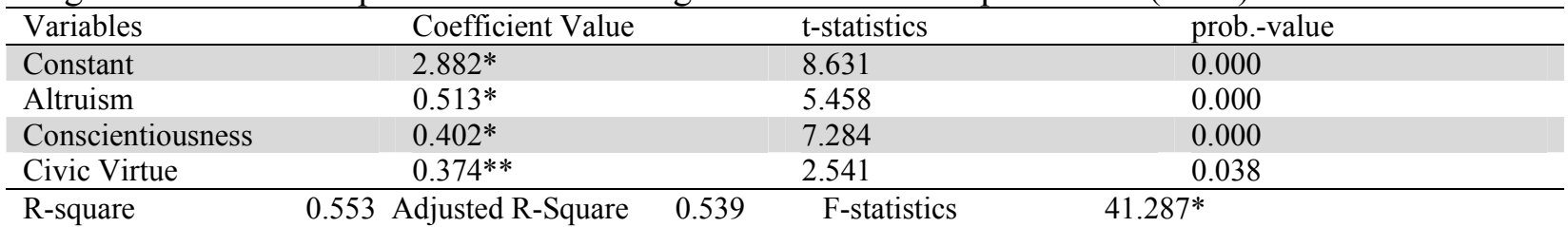

The results show that Altruism has a positive and significant relationship with OCB, which interprets that the teaching faculty has the qualities of helping their co-workers in any regard. Hence hypothesis one (H1) is accepted. The result is consistent with the previous research of Konovsky \& Organ (1996). Furthermore, conscientiousness has a significant positive relationship with OCB. It shows that teaching faculty in different institutes of KPK provinces of Pakistan are stay informed with up-to date knowledge about admissions, course curriculum, marketing campaigns and different other services offered by the universities. The result is consistent with the previous researchers i.e., Neihoff and Yen (2004) and Sansone et al. (1999). Finally, civic virtue has also a positive and significant impact with OCB, which shows that teaching faculty involved in the routine and non-routine matters of their respective universities for the projection of a good image among the universities of KPK province of Pakistan. The result is consistent with the previous research of Redman \& Snape (2005).

\subsection{Collinearity test}

The test to detect multicollinearity (variance inflation factor) is also performed to support the validity of the regression results. In case of VIF, if the result is below the 10 and tolerance is near to zero it suggests no multicollinearity (Gujarati, 2003). In Table 5, the results of VIF and tolerance factor are reasonably acceptable. The values of variance inflation factor for the variables in the model ranges from 1.201 to 4.873 for SIZE to GDP suggesting the absence of multicollinearity among the variables of the model. 
Table 5

Values of tolerance and variance inflation factor (VIF)

\begin{tabular}{lll}
\hline Variables & Tolerance & Variance Inflation Factor \\
\hline Altruism & 0.601 & 1.728 \\
Conscientiousness & 0.715 & 1.905 \\
Civic Virtue & 0.729 & 2.328 \\
\hline
\end{tabular}

\subsection{Incremental regression}

The incremental regression is performed by removing individual independent variables from the model and by checking the effect on the value of R-squared. Among all the variables removed, altruism has altered the value of R-squared to the highest degree, $26.4 \%$ decreases in the portion of the dependent variable explained by independent variables, as the value for the R-squared changes from $55.3 \%$ to 29.5 . This importance is also highlighted in the regression result as the value of coefficient of the variable $(0.513)$ is highest among all the variables. The result is presented in Table 6.

\section{Table 6}

Results of Incremental Regression removing altruism

\begin{tabular}{ll}
\hline Models & Values \\
\hline R-squared (original) & 0.553 \\
R-squared (after the removal of altruism) & 0.294 \\
\hline
\end{tabular}

\subsection{Factor analysis}

Factor analysis is used as criteria for validity. The result of principal component analysis shows that there are three factors whose Eigen-values exceed 1. The Eigen-value factor shows the amount of total variance explained by that factor. Three factors explained $51.311 \%$ of the total variance shown in Table 7. The first, the second and the third factors explained are $22.3 \%, 16.3 \%$ and $11.548 \%$ of this variance, respectively.

Table 7

Total variance explained

\begin{tabular}{lllllll}
\hline Initial Eigen values & \multicolumn{5}{c}{ Extraction Sums of Squared Loadings } \\
\hline Component & Total & \multicolumn{3}{c}{ \% of VarianceCumulative \% Total } & \% of VarianceCumulative \% \\
\hline 1 & 3.581 & 22.379 & 22.379 & 3.581 & 22.379 & 22.379 \\
2 & 2.621 & 16.384 & 38.763 & 2.621 & 16.384 & 38.763 \\
3 & 1.968 & 12.548 & 51.311 & 1.968 & 12.548 & 51.311 \\
4 & .998 & 8.119 & 55.430 & & & \\
5 & .910 & 7.153 & 62.583 & & & \\
6 & .889 & 6.619 & 69.203 & & \\
7 & .859 & 5.367 & 74.570 & & \\
8 & .695 & 4.346 & 78.916 & & & \\
9 & .675 & 4.221 & 83.137 & & & \\
10 & .615 & 3.846 & 86.983 & & & \\
11 & .493 & 3.083 & 90.066 & & & \\
\hline 12 & .452 & 2.826 & 92.892 & & & \\
\hline 13 & .358 & 2.238 & 95.131 & & & \\
\hline 14 & .341 & 2.128 & 97.259 & & & \\
\hline 15 & .314 & 1.965 & 99.224 & & & \\
\hline 16 & .124 & .776 & 100.000 & & & \\
\hline Note: Extraction Method: Principal Component Analysis & & & & \\
\hline
\end{tabular}


The component matrix is shown in Table 8. First factor "Affective Commitment" is constructed by nine scale items and accounted for the largest proportion, i.e., $22.3 \%$ of total explained variance. The second factor, "Continuance Commitment" is constructed by five scale items and accounted for $16.3 \%$ of variance. The third and the last factor i.e., "Normative Commitment" explained $12.5 \%$ of the total explained variance and was constructed by only two items.

\section{Table 8}

Component matrix

\begin{tabular}{llll}
\hline & Affective commitment & Continuance commitment & Normative commitment \\
\hline Q1 & .351 & & .508 \\
Q2 & & & \\
Q3 & .593 & .439 & \\
Q4 & & & \\
Q5 & .490 & & \\
Q6 & .680 & & \\
Q7 & .557 & & \\
Q8 & .679 & & \\
Q9 & .658 & .531 & \\
Q10 & .499 & .778 & \\
Q11 & & .744 & .690 \\
Q12 & & .508 & \\
Q13 & & & \\
Q14 & & & \\
Q15 & & & \\
Q16 & & & \\
\hline
\end{tabular}

Extraction Method: Principal Component Analysis. 3 components extracted.

\section{Conclusion}

The objective of this study was to invoke organizational citizenship behavior (OCB) in higher education institutes of Khyber Pakhtonkhuwa (KPK) province of Pakistan. Ninety four teaching faculty in different universities of KPK were involved in this study. The result supports the hypothesis of strong positive impact of antecedents on organization citizenship behavior in teaching faculties. Component matrix divide in three ultimate factors i.e., Affective Commitment, Continuance Commitment and Normative Commitment in which the largest proportion accounted for $22.3 \%$ of total explained variance for affective commitment.

It was found during the survey that most employees had no concept of OCB. The researchers made their honest efforts to make every respondent understand the questionnaire so that the research is productive. Finally, it is advised to the future researchers to include antecedents like tenure, salary, job satisfaction, etc. in their studies, as it was experienced that they may have an impact on the determining of OCB among the workforce of an establishment.

\section{References}

Allen, T., \& Rush, M. (2001). The influence of rate gender on ratings of organizational citizenship Behavior'. Journal of Applied Social Psychology, 31(12), 2561-2587.

Ball, G. A., Trevino, L. K., \& Sims, H. P., Jr. (1994). Just and unjust punishment: Influences on subordinate performance and citizenship. Academy of Management Journal, 37, 299-322.

Bacharach, D., \& Jex, S. (2000). Organizational citizenship and mood: An experimental test of perceived job breadth. Journal of Applied Social Psychology, 30(3), 641-663.

Baker, B. (2005). The good, the bad and the ugly: the mediating role of attribution style in the relationship between personality and performance. North Carolina: State University

Bateman, T.S., \& Organ, D.W. (1983). Job satisfaction and the good soldier: the relationship between affect and citizenship. Academy of Management Journal, 26, 587-595. 
Borman, W.C., \& Motowildo, S.J., (1993). Expanding the criterion domain to include elements of contextual performance. Personnel Selection in Organizations. Jossey-Bass, San Francisco.

Brennan, A., \& Skarlick, D. (2004). Personality and perceived justice as predictors of survivors' reactions following downsizing. Journal of Applied Social Psychology, 34(6), 1306-1328.

Brief, A. P., \& Motowidlo, S. J. (1986). Prosocial organizational behaviors. Academy of Management Review, 10, 710-725.

Coole, D.R. (2003). The effects of citizenship performance, task performance, and rating format on performance judgments, University of South Florida.

Farh, J. L., Podsakoff, P. M, \& Organ, D. W. (1990). Accounting for organizational citizenship behavior: Leader fairness and task scope versus satisfaction. Journal of Management, 16, 705-721.

George, J. M. (1990). Personality, sect, and behavior in groups. Journal of Applied Psychology, 75,107-116.

George, J. M., \& Bettenhawn, K. (1990). Understanding prosocial behavior, sales performance, and turnover: A group-level analysis in a serine context. Journal of Applied Psychology, 75, 698-709.

Gujarati, D. (2003). Basic Econometrics. $4^{\text {th }}$ Edition. McGraw Hill.

Jacqueline, A-M., Shapiro, C., Kessler, I., \& Purcell, J. (2004). Exploring organizationally directed citizenship behavior: Reciprocity or 'It's my job'?. Journal of Management Studies, 41(1), 85-106.

King, E., George, J., \& Hebl, M. (2005). Linking personality to helping behaviors at work: An international perspective. Journal of Personality, 73(3), 586-607.

Konovsky, M., \& Organ, D. (1996). Dispositional and contextual determinants of organizational citizenship behavior. Journal of Organizational Behavior, 17, 253-266.

Ladd, D., \& Henry, R. (2000). Helping coworkers and helping the organization: The role of support perceptions exchange ideology, and conscientiousness. Journal of Applied Social Psychology, 30(10), 2028-2049.

Lee, K., \& Allen, N. J. (2002). Organizational citizenship behavior and workplace deviance: the role of affect and cognitions. Journal of Applied Psychology, 87, 131-142.

Mackenzie, S.B., Podsakoff, P.M., Paine, J.B. (1999). Do citizenship behaviors matter more for managers than for salespeople? Journal of the Academy of Marketing Science, 27, 396-410.

Mackenzie, S. B., Podsakoff, P. M., \& Fetter, R. (1991). Organizational citizenship behavior and objective productivity as determinants of managerial evaluations of salespersons' performance. Organizational Behavior and Human Decision Processes, 50, 123-150.

Mackenzie, S. B., Podmkoff, P. M., \& Patter, R. (1993). The impact of organizational citizenship behavior on evaluations of salesperson performance. Journal of Marketing, 57, 70-80.

Moorman, R., Blakely, G., \& Neihoff, B. (1998). Does received organizational support mediate the relationship between procedural justice and organizational citizenship behavior. Academy of Management Journal. 41(3), 351-371.

Moorman, R. H, (1991). Relationship between organizational justice and organizational citizenship behaviors: Do fairness perceptions influence employee citizenship?. Journal of Applied Psychology, 76, 845-855.

Motowidlo, S.J., \& Von Scotter, J.R. (1994). Evidence that task performance should be distinguished from contextual performance. Journal of Applied Psychology, 79, 475-480.

Munene, J. C. (1995). "Not-on-Seat": An investigation of some commitments of organizational citizenship behavior in Nigeria. Applied Psychology: An International Review, 44(2), 111-122.

Niehoff, B. P., \& Moorman, R. H. (1993). Justice as a mediator of the relationship between methods of monitoring and organizational citizenship behavior. Academy of Management Journal, 36,527556.

Organ, D.W. (1988). Organizational Citizenship Behavior: The Good Soldier Syndrome. Lexington Books, Lexington, MA.

Organ, D. W., \& Konovsky, M. (1989). Cognitive versus affective determinants of organizational citizenship behavior. Journal of Applied Psychology, 74, 157-164. 
Organ, D. W., \& Ryan, K. (1995). A meta-analytic review of attitudinal and dispositional predictors of organizational citizenship behavior. Personnel Psychology, 48,775-802.

Organ, D.W. (1990). The motivational basis of organizational citizenship behavior. Research in Organizational Behavior, Greenwich, CT.

Podsakoff, P. M., Mackenzie, S. B., \& Bommer, W. (1996a). Transformational leader behaviors and substitutes for leadership as determinants of employee satisfaction, commitment, trust, and organizational citizenship behaviors. Journal of Management, 22,259-298.

Podsakoff, P. M., Mackenzie, S. B., \& Bommer, W. H. (1996b). Mata-analysis of the relationships between Kerr and Jermier's substitutes for leadership and employee job attitudes, role perceptions, and performance. Journal of Applied Psychology, 881,380-399.

Podsakoff, P. M., \& Mackenzie, S. B. (1994). Organizational citizenship behavior and sales unit effectiveness. Journal of Marketing Research, 31, 351-363.

Podsakoff, P. M., Mackenzie. S. B., \& Hui, C. (1993). Organizational citizenship behaviors as determinants of managerial evaluations of employee performance: A review and suggestions for future research. In G. R. Ferris \& K. M. Rowland (Eds.), Research in Personnel and Human Resources Management, 11, 1-40).

Podsakoff, P. M., Mackenzie, S. B., Moorman, R. H., \& Fetter, R. (1990). Transformational leader behaviors and their effects on followers' trust in leader, satisfaction, and organizational citizenship behavior. Leadership Quarterly, 1, 107-142.

Puffer, S. M. (1987). Prosocial behavior, noncompliant behavior, and work performance among commission salespeople. Journal of Applied Psychology, 72.615-621.

Redman, T., \& Snape, E. (2005). I to Wed: The role of consciousness transformation in compassion and Altruism. Journal of Management Studies, 42(2), 2200-2380.

Roberts, et al. (2005). The Structure of Conscientiousness: An Empirical Investigation Based on Seven Major Personality Questionnaires. Personal Psychology, 58, 103-139.

Sansone. C., Wiebe, D., \& Morgan, C. (1999). Self-Regulating Interest: The Moderating Role of Hardiness and Conscientiousness. Journal of Personality, 67(4). 701-733.

Schnake, M. (1991). Organizational citizenship: A review, proposed model, and research agenda. Human Relations, 44,735-759.

Smith, C. A., Organ, D. W., \& Near, J. P. (1983). Organizational citizenship behavior: Its nature and antecedents. Journal of Applied Psychology, 68,655-663.

Turnipseed, D., \& Rassuli, A. (2005). Performance Perceptions of Organizational Citizenship Behaviors at Work: A Bi-Level Study Among Managers And Employees. British Journal of Management, 16, 231-244.

Vieten, C., Amorok, T., \& Schlitz, M. (2005). The Role of Consciousness Transformation in Compassion and Altruism. The Joint Publication Board of Zygon, 41(4), 915-932.

Williams, L. J., \& Anderson, S. E. (1991). Job satisfaction and organizational commitment as predictors of organizational citizenship and in-role behavior. Journal of Management, 17, 601617.

Yen, H. R., Niehoff, B. P. (2004). Organizational citizenship behaviors and organizational Effectiveness: Examining relationships in Taiwanese banks. Journal of Applied Social Psychology, 34(8), 1617-1637.

Yorges, S. (1999). The impact of group formation and perceptions of fairness on organizational citizenship behaviors. Journal of Applied Social Psychology, 29(7), 1444-1471. 